$\begin{array}{lllllll}\text { (c) EUSP, } 2019 & \text { e } & \text { ISSN 2310-3817 } & \text { Vol.7 } & \text { SICSS } & \text { No.1 } & \text { p. 340-362 }\end{array}$
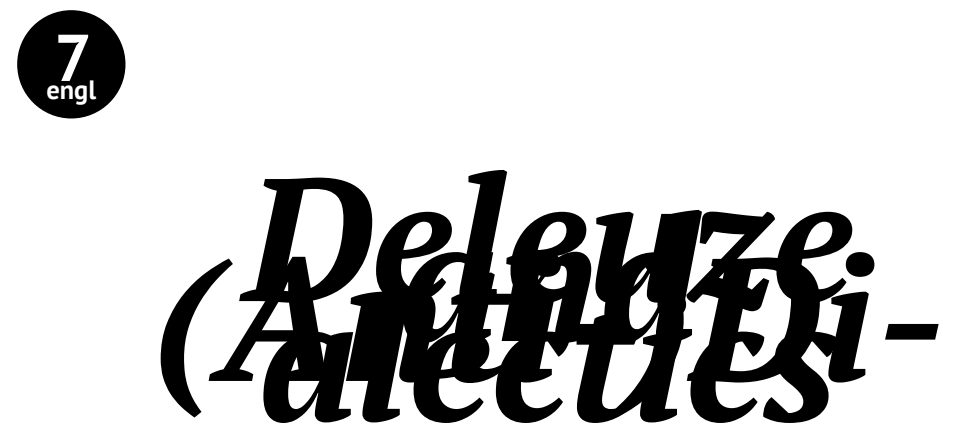

\title{
Ksenia Kapelchuk
}

Teaching Assistant, ITMO University, 49 Kronverksky Pr., St Petersburg, Russia 197101

E-mail: ksenya_ka@list.ru

\section{Deleuze and (Anti)Dialectics}

\begin{abstract}
The article analyzes the critique of dialectics within the philosophy of Gilles Deleuze and the response to this critique that has been proposed by Slavoj Žižek. As a rule, Deleuze's philosophy is considered to be anti-dialectical and anti-Hegelian. In lieu of this interpretation, Žižek has proposed an alternative reading whereby, Deleuze himself appears to be a dialectician and a Hegelian. The article attempts to answer the following question: in what sense can we consider Deleuze's philosophical project to be a dialectical one? The author reveals the different meanings of dialectics that are explicitly present in Deleuze's works and also conducts an analysis of the implicit similaritiesas identified by Žižek-between Deleuze's arguments and Hegel's philosophy. Thus, the author offers a comparative analysis of the concepts shared by Hegel and Deleuze (the virtual, chance, repetition), distinguishing between Deleuze's and Hegel's projects, as well as between their respective interpretations by Žižek.
\end{abstract}




\title{
For Deleuze
}

\author{
Keywords \\ dialectics, Deleuze, Hegel, Žižek, virtuality, chance, repetition, \\ Chronos, Aion
}

In recent years, continental philosophy has been undergoing a process that could be described as the revival of Hegel's dialectics. ${ }^{1}$ The Slovenian philosopher Slavoj Žižek has played a significant role in this process, and it is he who seems to have most clearly formulated the issue of the nature of dialectics' presence in modern philosophy. The problematic nature of this presence is primarily due to the break that was inscribed within the history of dialectical thought itself: the decline it experienced and the criticism that was put forward against it.

Can one still be a Hegelian after the post-Hegelian break with traditional metaphysics which occurred more or less simultaneously in the works of Schopenhauer, Kierkegaard, and Marx? [...] Although it presents itself as a break with idealism as embodied in its Hegelian climax, it ignores a crucial dimension of Hegel's thought; that is, it ultimately amounts to a desperate attempt to go on thinking as if Hegel had not happened. The hole left by this absence of Hegel is then, of course, filled in with the ridiculous caricature of Hegel the "absolute idealist" who "possessed Absolute Knowledge.” The reassertion of Hegel's speculative thought is thus not what it may appear to be-a denial of the post-Hegelian breakbut rather a bringing-forth of that very dimension whose denial sustains the post-Hegelian break itself. (Žižek 2012: 124)

Thus, the idea is that post-Hegelian metaphysics did not have anything to do with the original message of Hegel's thought-its criticisms missing the mark each time. The task set before Žižek and those who pursue a similar direction to him appears to be twofold: to elucidate the dimension of Hegel's philosophy that has been overlooked in post-Hegelian metaphysics-which proclaims itself anti-dialectical-and to show that the theoretical intrigue of many post-Hegelian "anti-dialectical" concepts still depends upon problems identified by Hegel through dialectics. As for Žižek, he formulates his position in the following way: "If you ask me at gunpoint what I would like to do, I will answer that in fact, I would like to

1 Among the most important explorations of the role of Hegel's figure in the modern philosophical context, we can mention works by Rebecca Comay (Comay 2011; Zandvoort and Comay 2018), Catherine Malabou (Malabou 2004; 2009a; 2009b; Malabou and Butler 2010), and Susan Buck-Morss (2009). 


\section{Ksenia Kapelchuk}

make Hegel relevant. [...] Everything that came after Hegel was a misunderstanding” (Žižek 2007: 8).

For those seeking to rehabilitate dialectics within modern philosophy, one apparent task has been to criticize the philosophy of Gilles Deleuze-the iconic 20th century figure whose work appears to call for the replacement of Hegel's dialectics, the philosophy of negation and contradiction, with the philosophy of difference. Alain Badiou approaches this critical challenge in his own way with his book Deleuze: The Clamour of Being;. Žižek does it too: he dedicated one of his works-Organs Without Bodies: Deleuze and Consequences (2004a) - to Deleuze, commenting on Deleuze's approaches in the book on Hegel in detail (Žižek 2012). However, while Badiou-in characterizing Deleuze's method as "anti-dialectical ," attempts to clarify the difference between the philosophical premises of Deleuze's concepts and the theoretical background of his own thought (thereby leaving room for Deleuze's tacit disagreement ${ }^{2}$ )-Žižek seeks to appropriate Deleuze's schemes, with his exasperating approach invoking righteous anger among Deleuzians ${ }^{3}$ (Sinnerbrink 2006; Smith 2004):

He is trying to use Deleuze's own weapon against him and paint him as a crypto-Hegelian, besides not too impressive a sample. [...] Now Deleuze turns out to be one of Bogdanov's followers, who the ghost of the dialectical materialist opposes, then he wrongly interprets the logic of negativity, or merely demonstrates his inability to read Hegel. One way or another, he is Hegel's closest relative, even though he is unaware of it. In other words, Deleuze is a standard example of a neurotic: a neurotic claims that he is a child of "different parents" - sometimes more noble ones, other times not. Deleuze is forced to return "home": to his German

2 "On this particular point, Deleuze did not pursue the discussion in detail. I take it up here, but find the fact that he is no longer there to rejoin somewhat disconcerting. How I would so like him to point out to me once again, as he did with great relish in so many different passages, to what extent my philosophy has a reflexive, negative, or analogical value - by which he meant an antivalue, a constellation of the most dire faults - and that it forms a transcendence, with all the attributes of the Kantian Idea!” (Badiou 2006: 75-76).

3 One could speak of the existing confrontation regarding the interpretation of the relation between Deleuze's thought and Hegel's philosophy. In this context, Robert Sinnerbrink discerns two polar approaches to Deleuze's philosophy: "the radical separatist" interpretation, to which Deleuze himself adheres, as well as the majority of those commenting on his works and insisting on the fact that there is a fundamental confrontation between Deleuze and Hegel, and the "recidivist" or "assimilationist" reading, which is characteristic of philosophers trying to reconcile them. Apart from Slavoj Žižek, in the second group the author also includes Judith Butler and Catherine Malabou (Sinnerbrink 2006: 64). 
family where no one had awaited him. The parents would have been even more perplexed by their offspring than the offspring himself. (Kralechkin 2006)

But does questioning Deleuze's attitude towards dialectics necessarily imply wondering about his "parents", or even about Hegel in particular? Is not dialectics itself a sort of a comprehensive "family-like" notion?

\section{Dialectics: One or Many?}

The famous thesis that Deleuze formulated in his work Difference and Repetition states: "difference and repetition have taken the place of the identical and the negative, of identity and contradiction" (Deleuze 1998: 9). Does this thesis have anything in common with the attempt to incapacitate dialectics by deactivating the negation of the negation mechanism? It is Deleuze himself who provokes such an interpretation by gathering the whole tradition of "anti-dialectical" philosophers-enlisting Friedrich Nietzsche, Søren Kierkegaard, Friedrich Schelling, Henri Bergson, and others-to fight against Negation, Identity, Notion, Contradiction, and Mediation; that is, against all the symbols of Hegel's philosophy. Here he largely repeats the theses expressed earlier in the book $\mathrm{Ni}$ etzsche and Philosophy (perhaps the most anti-Hegelian of his works), which is permeated by the critique of dialectics as a form of nihilism. In this work, dialectic is presented as nothing more than the point of view of the vindictive slave:

The man of ressentiment needs to conceive of a non-ego, then to oppose himself to this non-ego in order finally to posit himself as self. This is the strange syllogism of the slave: he needs two negations in order to produce an appearance of affirmation. We already sense the form in which the syllogism of the slave has been so successful in philosophy: the dialectic. The dialectic, as the ideology of ressentiment. (Deleuze 2006: 113)

Deleuze's verdict on dialectics, and dialectics of a predominantly Hegelian kind, is that it is forced to speak about opposites, the development and resolution of contradictions, as "[i]t is unaware of the real element from which forces, their qualities and their relations derive" (Ibid.: 148-149).

As a result, the modern rehabilitation of Hegel and dialectics often turns against Deleuze's philosophy, which is perceived largely through the prism of reading Deleuze as an affirmationist philosopher and vitalist. Does this mean that dialectics has incorporated Deleuze's duo of differ- 
ence and repetition? Have we really been dealing with the decline of dialectics up until now? And if we were indeed witnessing a rivalry, what would the criteria for crowning the victor be?

To speak of the anti-dialectical nature of Deleuze, it is necessary to indicate how dialectic is interpreted. Hegel's understanding of dialectic presupposes the idea of a certain progress: there are different types of dialectics, and they are organized as an ascent to the method of Hegel himself, which plays a key role in any possible philosophical enterprise:

How could I possibly pretend that the method that I follow in this system of logic, or rather the method that this system itself follows within, would not be capable of greater perfection, of greater elaboration of detail? Yet I know that it is the one and only true method. This is made obvious by the very fact that this method is not something distinct from its subject matter and content - for it is the content in itself, the dialectic which it possesses within itself, which moves the subject matter forward. It is clear that no expositions can be accepted as scientifically valid that do not follow the progression of this method and are not in tune with its simple rhythm, for it is the course of the fact itself. (Hegel 2010: 33)

However, dialectics does not reach such a scale immediately. One can point to two examples of dialectics mentioned by Hegel, which, according to him, prove to be insufficient to present "the course of the fact itself": these are the ancient dialectic of Plato and the Kantian dialectic. According to Hegel, both of them, revealing the difference between two judgments and establishing a relationship of contradiction, do not perform an immanent transition of one into the other and remain within external reflection. However, if Kant demonstrates "the objectivity of reflective shine and the necessity of the contradiction which belongs to the nature of thought determinations"-without removing this contradiction, but at least freeing dialectics from "the semblance of arbitrariness" (Ibid.: 34)Platonic dialectic "comes only to a negative result," as an external and negative activity that refutes limited assertions (Ibid.: 34-35). At the same time, Hegel even occasionally places the dialectical moves of ancient thinkers such as Parmenides, Heraclitus, and Aristotle above Kantian dialectics (Ibid.: 164-165). However, these individual moves cannot be said to be systematic. Thus, Hegel presents the Eleatic, Platonic, Aristotelian, and Kantian dialectics as unfinished forms of a single dialectic, in which they find their final truth.

As for Deleuze, in my opinion, he offers at least three interpretations of the dialectical method, and his position in each one of them is not as straightforward as Badiou presents it to be. Badiou defines Deleuze's method as the negation of dialectics (Badiou 2006: 31) and dialectics as "a 
method of mediations that claims to internalize the negative" (Ibid.: 32). I proceed from the premise that in Deleuze's works we deal not with a single dialectic, as in the case of Hegel, but with multiple dialectics to which the author's attitude is very different.

So what are these three interpretations of dialectics? The first interpretation, presented in Nietzsche and Philosophy, is the most radical and critical. Already here, Deleuze distinguishes several "avatars"4 of dialectics. These are first and foremost Socrates and Hegel. "Dialectics is [...] the death of tragedy, the replacement of the tragic vision by a theoretical conception (with Socrates) or a Christian conception (with Hegel)" (Deleuze 2006: 18). Meanwhile, Plato is mentioned here less frequently and without any direct link to dialectics: it is Socrates whom Deleuze calls a dialectician, focusing on completely different elements from those he isolates in his critique of Plato, as will be mentioned later. Deleuze realizes Nietzsche's "[t]rying to characterise Plato without Socrates" (Ibid.: 210) in such a way that Plato is practically situated beyond the critique of Socratic dialectics as a theoretical approach to life. Reproducing the logic of Nietzsche's move in relation to nihilism, Deleuze critiques dialectics through a criticism of dialecticians - posing the question that, according to Deleuze, is overlooked by dialectics itself: The question "who?" (Ibid.: 160).

In addition to Socrates and Plato, Deleuze here mentions another classic author who is commonly considered to have been at the source of the dialectical method: Heraclitus. But he, as a matter of fact, finds himself in the opposite camp to Hegel. As for Hegel's dialectics, it is described as a false development of Kant's critique, whereas its real outcomes, according to Deleuze, are revealed by Nietzsche. Hegel's theme of the negative is picked up by Stirner and Marx. Thus, at this stage, it is possible to note not only the opposition of Deleuze and Hegel with respect to dialectics, but also the discrepancy between their descriptions of its genealogy.

Later, in his article "The Overthrow of Platonism" (1966), ${ }^{5}$ Deleuze would move on to the study of the other side of the call to action to "[try] to characterise Plato without Socrates" (Ibid.: 210). This time the text would not be dedicated to Socrates's theoretical attitude to life as the source of dialectics but instead to Plato's method as a dialectical method. If previously the method studied and at the same time applied by Deleuze was critique, in "The Overthrow of Platonism" he appeals to "reversal." "To overthrow Platonism" (Deleuze 1983b: 52) is another of Nietzsche's projects, and revealing its meaning is the purpose of Deleuze's discourse.

$4 \quad$ Deleuze cites Merleau-Ponty: "The dialectic has fewer adventures than avatars" (Deleuze 2006: 217).

The work was later republished in 1969 under the title Plato And The Simulacrum. 


\section{Ksenia Kapelchuk}

According to Deleuze, Nietzsche's overthrow has to do with the true motive of Platonism: the will to selection and the division method, i.e., dialectics. In other words, here Deleuze's move is no longer to distinguish his thought (and Nietzsche's thought) from the dialectical, as it used to be, but to non-dialectically (in the Hegelian sense) study a dialectics - in the Platonic sense - of a particular kind:

Platonism is the Odyssey of philosophy. The Platonic dialectic is not a dialectic of contradiction nor of contrariety, but one of rivalry (amphisbetesis)- a dialectic of rivals or claimants. [...] It is the property of division [...] to join, internally, the power of dialectic with that of myth. [...] it is a matter of choosing claimants, of distinguishing the good from the false copies, or even more, the always well-founded copies from the simulacra, ever corrupted by dissemblance. (Ibid.: 46, 48)

There is clearly a certain shift here in the understanding of dialectics: now it involves not only Hegel's contradiction, but also Plato's selection. Moreover, returning to Nietzsche and Philosophy, it is conspicuous that there the notion of selection had also played an important role: it described the way of being as an eternal return, one of the central terms of Deleuze's philosophy. Instead, here the method of selection is attributed to Platonism. Essentially, the reversal of Platonism consists precisely in relieving selection of the moral requirement to retain the simulacrum and becoming-mad at maximum depth. It is the liberation of these spaces and bringing them to the surface of things that, according to Deleuze, takes place in Nietzsche's reversal of Platonism.

Anti-Platonism and Deleuze's anti-dialectical approach appear to be ambiguous in this context. On the one hand, in his interpretation of Plato's works selection is deemed to be a flawed process, as it makes the image subordinate to the copy, expels the simulacrum and imposes the rule of "the Same," which, subsequently,-via Aristotle and Hegel-leads to the completion of the representational system. On the other hand, it is through Plato and his dialectics that one manages to object to Aristotle: "[Was it not inevitable] that Plato be the first to indicate this direction for the overthrow of Platonism?" (Ibid.: 47). As a result, in Deleuze's very manner of describing Plato's selection - "[the method] masters all the power of the dialectic" (Ibid.: 45) - it is not only notes of criticism that one can detect, but also a tone of admiration.

Finally, the third version of dialectics is found in Difference and Repetition. Here Deleuze once again clarifies his relationship with Plato, Nietzsche, and Hegel, constructing a new, more comprehensive theory of the dialectical. He continues to develop his thought in the direction outlined in his text about Plato - that is, the line dividing Plato's and Hegel's dialectics, which ultimately allows him to take yet another step. During 
the period marked by Nietzsche and Philosophy, Deleuze had only critiqued the dialectical method, pointing to its nihilistic source. Later, in "The Overthrow of Platonism", he interprets dialectics in a dual way: here, it is Hegel's dialectics of the negative and Plato's dialectics of division and selection, with the latter opening the way to becoming and simulacrum. Finally, in Difference and Repetition, Deleuze develops his own dialectical theory: "the dialectic of problems and questions." The latter, as in the first two cases, is a critique of the dialectic of negativity, but now it does not merely set the dialectics of selection against it, but also includes “(non)-being” as a necessary element. Thus, first of all, Deleuze assumes the name of dialectician, and second, interpreting (non)-being as the being of the problematic, he redefines (i.e., in a sense, masters) what lies at the core of Hegel's dialectics, which he criticizes: negativity.

The Hegelian dialectic is realized through the movement of a concept in reflexive self-mediation, which in turn grows out of the unfolding of reflection: from positing reflection through external reflection and towards determining reflection. Hegel's reproach to the dialectics of Plato and Kant is that this reflection is not brought to an end. Deleuze sees this interrupted movement of reflection as a positive moment in the dialectics of the Idea. The Idea, unlike a concept, is not yet included in the system of distribution of identities and differences, organized according to the commonality of the genus and the characteristics of the species ${ }^{6}$; and is interpreted by Deleuze as something problematic. Deleuze contrasts the traditional metaphysical move and the movement from hypothesis to apodicticity (here we can also include the sequence of the three types of Hegelian reflection) with a different movement: the one from the problematic (le problématique) to the question. The Idea represents a problem; it opens access to the key principle of Deleuze's ontology: the displacement of the virtual element. Deleuze, in this sense, speaks of "the long history of the distortion of the dialectic, which culminates with Hegel":

[It] consists in substituting the labour of the negative for the play of difference and the differential. Instead of being defined by a (non)-being

6 Of course, in Hegel's works this notion violates the genus-species relation too. As Žižek describes this violation: "the fundamental Hegelian logical principle” is that "the two species of the genus are the genus itself and its one species" (Žižek 1997: 92). As for Deleuze, he speaks of the "orgiastic" nature of Hegel's concept, in which the eternal is introduced. But here the problem for Deleuze is that eventually orgiasticity still turns out to be subordinate to the organic: "The ultimate wish of the organic is to become orgiastic and to conquer the in-itself, but this effort found two culminating moments in Leibniz and Hegel. [...] Nothing, however, has changed: difference remains subject to malediction, and all that has happened is the discovery of more subtle and more sublime means to make it atone, or to redeem it and subject it to the categories of representation" (Deleuze 1994: 262-263). 


\section{Ksenia Kapelchuk}

which is the being of problems and questions, the dialectical instance is now defined by a non-being which is the being of the negative. (Deleuze 1994: 268)

Here even Marx-whom Deleuze decisively does not accept in his work Nietzsche and Philosophy - finds himself on the side of the philosophy of difference (Ibid.: 207).

According to Deleuze, contrary to the common thesis, it is not between the statement ("being is") and the negation ("being is not") that the distinction is drawn in favor of the first, but between the two interpre-

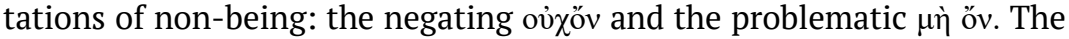
first is interpreted by Deleuze only as the effect of asserting differentiation, like a shadow turning to flesh within the framework of representation and creating an illusion that, on the contrary, the assertion is the effect of negation. ${ }^{7}$ Thus Deleuze points to the double reversal of dialectics: the first being Hegel's, in relation to Plato-and then to his own, in relation to Hegel. And if the first reversal occurs as the completion of the concept's representational system, to which the Idea understood in Deleuze's terms is applied, the second is related to the identification of an "objectively false" movement.

In addition, it is worth mentioning that in Logic of Sense 1990 [1969] Deleuze also uses the term dialectics in a positive way, yet without providing a detailed explanation for such a gesture. It is the event itself that turns out to be dialectical if understood in the Stoic sense. Deleuze calls for a differentiation of the dialectic of the Stoics from Plato's dialectic, contrasting Socratic irony as the art of depth with Stoic humor as the art of surface: "[t]he Sophists and Cynics had already made humor a philosophical weapon against Socratic irony; but with the Stoics, humor found its dialectics, its dialectical principle or its natural place and its pure philosophical concept" (Deleuze 1990: 9). It is in the Stoics' works that Deleuze finds the operation with meaning that could be called dialectics and that determines the essence of dialectical thought:

$7 \quad$ In criticizing the notion of negation, Deleuze in no way returns to the forms of pure assertion negating negation, but shifts it, eluding the imposition of the "dubious alternative: in seeking to dispel the negative, we declare ourselves satisfied if we show that being is full positive reality which admits no non-being; conversely, in seeking to ground negation, we are satisfied if we manage to posit, in being itself or in relation to being, some sort of non-being (it seems to us that this non-being is necessarily the being of the negative or the ground of negation). The alternative is thus the following: either there is no non-being and negation is illusory and ungrounded, or there is non-being, which puts the negative in being and grounds negation. Perhaps, however, we have reasons to say both that there is non-being and that the negative is illusory" (Deleuze 1994: 63). 
Perhaps the Stoics used the paradox in a completely new manner-both as an instrument for the analysis of language and as a means of synthesizing events. Dialectics is precisely this science of incorporeal events as they are expressed in propositions, and of the connections between events as they are expressed in relations between propositions. Dialectics is, indeed, the art of conjugation (see the confatalia or series of events which depend on one another). (Ibid.: 8)

Deleuze's works of the late 1960s, Difference and Repetition (1994) and Logic of Sense, mark the point of his closest rapprochement with dialectics. The next period-Deleuze's joint work with Félix Guattari-is associated with the return to a critique of dialectics, primarily of the Hegelian type. In Anti-Oedipus, ${ }^{8}$ it is critiqued as a concept of gradual development that juxtaposes the parts and the whole in such a way that the former become subordinate to the latter, in a totalizing moment (which, from the authors' point of view, represents an error typical of mechanism and vitalism) (Deleuze and Guattari 1987: 43). In A Thousand Plateaus, the opposition of non-dialectical multiplicity and the dialectized pair of the One and the multiple ${ }^{9}$ is joined by a motif related to language analysis in the field of expression: the Stoic theory of expression is contrasted with a dialectical intermingling of content and expression of a conventionally Marxist nature (Ibid.: 44). In both cases, dialectics is is situated somewhat on the periphery of the main plots and does not act as a privileged object of criticism. It receives more attention in the work What is Philosophy? (1994), where Deleuze once again reviews the foundations of ancient dialectics. For the most part, however, he repeats what has already been said: that Plato's dialectics was represented by selection, while Aristotle's philosophy transformed dialectics into a conjugation, though not of events, as for the Stoics, but opinions, which transformed philosophy into "interminable discussion" (Deleuze and Guattari 1994: 79), and so on.

For the last time, Deleuze refers to dialectics in his work Cinema: here, dialectics no longer bears negative connotations - it is considered not as a philosophical practice, but instead as "a conception of images and their montage" (Deleuze 1997: 180). Cinematic dialectic, immersed in the

8 Despite the fact that some constructions in Anti-Oedipus can be compared to Hegel's schemes-as, for instance, illustrated by D. Kralechkin in their afterword to the book's Russian edition (Kralechkin 2007: 655) - the explicit pathos of Anti-Oedipus remains anti-Hegelian and, in this sense, also anti-dialectical.

9 "Let us return to the story of multiplicity, for the creation of this substantive marks a very important moment. It was created precisely in order to escape the abstract opposition between the multiple and the one, to escape dialectics, to succeed in conceiving the multiple in the pure state, to cease treating it as a numerical fragment of a lost Unity or Totality or as the organic element of a Unity or Totality yet to come, and instead distinguish between different types of multiplicity” (Deleuze 1987: 32). 
matter of movement, avoids the traps into which classic dialectic had inevitably fallen, seeking-according to Deleuze, to no avail - to reproduce this movement.

The latter is the order of transcendental forms which are actualised in a movement, while the former is the production and confrontation of the singular points which are immanent to movement. Now this production of singularities (the qualitative leap) is achieved by the accumulation of banalities (quantitative process), so that the singular is taken from the any-whatever, and is itself an any-whatever which is simply non-ordinary and non-regular. (Deleuze 1997: 6)

Dialectic as a method of a Soviet school of montage is not reduced to a single theory, which allows Deleuze to once again demonstrate the multiplicity of dialectic: that of Sergei Eisenstein and Dziga Vertov, Vsevolod Pudovkin and Alexander Dovzhenko.

Thus, speaking of the opposition of Hegel as dialectician and Deleuze as vitalist means allowing for a rather radical simplification. Having begun with a harsh criticism of everything related to dialectics, in the late 1960s, Deleuze comes closest to it. He attempts to construct his own dialectical concept: differently to Hegel, moving in line with a Platonic, Kantian, Kierkegaardian tradition, which resists Hegel (as Deleuze understands him), and brings to the fore the non-being of the problematic in contrast with non-being as negativity. And this is exactly where Žižek takes Deleuze at his word:

Deleuze is here unexpectedly close to Hegel [...] The passage to the next "higher" stage of the dialectical process occurs precisely when, instead of continuing to search for a solution, we problematize the problem itself (italicised by the author) abandoning its terms - when, for example, instead of continuing to search for a "true" State, we drop the very reference to the State and look for a communal existence beyond the State. (Žižek 2012: 137)

It is Žižek who carries out one of the most incisive attempts to erode the contradiction between Deleuze's and Hegel's projects. ${ }^{10}$ However, he

10 Attempts to bring together Deleuze's philosophy and dialectic can imply completely different aims: 1 ) to show that Deleuze's philosophy shares the theoretical premise of dialectical thought, but misses the kernel of dialectic - "negativity" - due to various circumstances, and as a result does not understand itself and risks becoming its "Guattarianized" seamy side (as Žižek argues in his works); 2) to show how at certain periods of developing his thought, Deleuze remained an incomplete anti-Hegelian and failed to avoid following a dialectical scheme - thereby highlighting the radicality of Deleuze's anti-dialectics in his works from other periods (thus Sinnerbrink speaks of "the "young" Deleuze" from the times of Nietzsche and Philosophy as of an ardent anti- 
sees this contradiction primarily as a confrontation of the dialectic and anti-dialectic, while the intrigue of this story can be presented in a different way: as a confrontation of the idea of dialectic with dialectics' multiplicity. To move forward, it is necessary to shift the angle of consideration from the level of statement to the level of the concepts' functioning.

\section{Chance, the Virtual, and Repetition}

In Žižek's reading of Deleuze, it is not merely that he goes too far, but that Deleuze goes so far in criticizing Hegel and dialectics that he occasionally almost coincides with Hegel. Criticizing the traditional idealistic image of Hegel, Deleuze, according to Žižek, makes his way to the truth that is the true core of Hegel's philosophy. ${ }^{11}$ But does not Žižek, by bringing Hegel and Deleuze this close together, himself risk coinciding with the latter?

Since the task is now to analyze those theses in which, according to Žižek, Deleuze and Hegel speak of the same, I would like to highlight and briefly analyze the three concepts with which, on the one hand, Žižek interprets Hegel and, on the other hand, represent the central concepts of Deleuze's philosophy: chance, the virtual, and repetition.

Deleuze interprets Hegel in his own way: for him, negation and mediation are necessarily refer to generality and a certain final identity. It is this reading that Žižek rejects:

[..] "conceiving the Absolute as Substance, not as Subject" - we are still surmising that there is some pre-existing Spirit imposing its substantial Necessity on history, while accepting that knowledge of this Necessity is denied us. To be consistently Hegelian, however, we must take a crucial step further and insist that historical Necessity does not pre-exist the contingent process of its actualization, that is, that the historical process is also in itself "open," undecided - this confused mixture "generates sense insofar as it unravels itself". (Ibid.: 139)

Hegelian whose critical stance did not escape a residual dialectical aspect [Sinnerbrink 2006: 64]); 3) to show how Deleuze, despite his anti-dialectical pathos, surreptitiously relies on his own implicit non-Hegelian dialectic (as an example, Eleanor Kaufman [2012] realizes this scenario in her own way [Kaufman 2012]). The latter method of dealing with this problem is probably most similar to what I am trying to argue in this text - however, on other grounds than Kaufman.

${ }_{11}$ At the same time, like Badiou, Žižek divides Deleuze's works into two periods: before and after the encounter with Felix Guattari. It is the first period that encompasses those of Deleuze's works which, from Žižek's point of view, deserve the most attention and can be interpreted within a Hegelian-Lacanian framework (Žižek 2004b: xi, 20-21). 
In this way, the move in Hegel's philosophy, which relies on the subject, consists in introducing a special temporality that goes against the linear temporal order of causality; Žižek calls this temporality retroactive. It is this dialectical turn, introducing contingency not merely as the flipside of necessity, but as an element producing this necessity in a retroactive manner - that is, in Žižek's opinion-overlooked by the critics of dialectics. Here in Žižek's interpretation, Hegel and Deleuze appear strikingly unanimous, as the focus of their projects is the imperative of asserting contingency. "The most difficult thing is to make chance an object of affirmation, but it is the sense of the imperative and the questions that it launches" (Deleuze 1994: 198), as Deleuze describes the purpose of his dialectics. "Yes, Hegel sublates contingency in a universal rational order - but this order itself hinges on a contingent excess" (Žižek 2012: 144), Žižek insists (2012: 144), justifying chance through the form of the retroactive dialectical scheme.

Another concept that plays an extremely important role in this context is the notion of the virtual, which both Žižek and Deleuze propose to understand as something fundamentally different from "potential." If potentiality understood in the Aristotelian sense turns out to be a not-yetcarried-out actuality (the motion is directed from the former to the latter, the present appears to derive from the past), virtuality points to such a moment in the past that was actualized retroactively - as one that has always been present but that is derived from the present. Usually associated with the future, the dimension of possibility is implanted into the past as "the open Whole"; this gesture, according to Žižek, unites Hegel, Benjamin, Freud, and Deleuze. Actualization does not embody the already potentially available virtual, but it retroactively casts the shadow of its possibility into the past, pointing to the dimension of the virtual.

For we Hegelians, the crucial question here is this: where does Hegel stand with regard to this distinction between potentiality and virtuality? On a first approach, there is massive evidence that Hegel is the philosopher of potentiality: is not the whole point of the dialectical process as the development from In-itself to For-itself that, in the process of becoming, things merely "become what they already are" (or were from all eternity)? Is not the dialectical process the temporal deployment of an eternal set of potentialities, which is why the Hegelian System is a selfenclosed set of necessary passages? This mirage of overwhelming evidence dissipates, however, the moment we fully take into account the radical retroactivity of the dialectical process: the process of becoming is not in itself necessary, but is the becoming (the gradual contingent emergence) of necessity itself. (Ibid.: 147) 
From Žižek's point of view, the place of virtuality in Hegel's works is taken by the subject, understood as nothing, and from it - that is, ex nihilo, or randomly - a new dialectical turn appears, a new event, which, together with its appearance, establishes its own necessity in the past.

Resorting to the concepts of actuality and virtuality in explaining the paradoxes of retroactivity and causality, Žižek openly refers to Logic of Sense and Difference and Repetition. He comments on the three Deleuzian concepts that juxtapose the virtual and actuality in the dialectical way: the pure past, the Idea, and the pure difference. The context of the use of these terms is dual: firstly, it is the context of dialectically understood historicity, and secondly, the context of the structure of the entire dialectical system in general. In other words, the question of the relationship between the virtual and actuality turns out to be key for both history and logic.

The "pure past" is not merely some past present, it paradoxically correlates with all times and events, be they past, present or future, bearing an element of fate. However, its virtuality works in such a way that this absolute element of the past turns out to be retroactively redefined in the present (Ibid.: 209, 613). Here the figure of "the open Whole" reappears; its invention Žižek attributes to dialectical philosophy:

[...] how this eternal pure past which fully determines us is itself subjected to retroactive change? We are thus simultaneously less free and more free than we think: we are thoroughly passive, determined by and dependent on the past, but we have the freedom to define the scope of this determination, to (over)determine the past which will determine us. (Ibid.: 135)

Introduced by the Stoics, the difference between corporeal things and incorporeal effects, ideas, meanings, or events - the former being actual and the latter virtual $-\mathrm{s}$ extremely important for Deleuze's ontology. Causal relations as such are inherent in the order of actual things, but the actual order also causes virtual effects (meanings, ideas, and events) through the operation of expression. Ideas, being passive and expressed entities, enter into relations with other ideas by the principle of quasireasons. And Deleuze's interpretation of the "Idea" is again interpreted by Žižek through the logic of retroactivity, being inscribed in the context of Hegel's dialectics. Here the key element for Žižek is that changes in the ideas, according to Deleuze, happen "[o]nly through the changes in actual things which express Ideas, since the entire generative power lies in actual things" (Ibid.: 138). Such an interpretation of the virtual gives Žižek an opportunity to refute the idea of dialectics being a method that adjusts the actual reality to the pre-existing, gradually opening a "closed whole," or to the pre-established idea that exists independently from this actual 
reality. According to the presented logic of retroactivity, the idea itself appears and is generated through changes in actuality at a contingent moment that redefine the overall structure; and dialectics is a theory of mechanism, or even the very mechanism of such generation.

Yet already here the radical difference between Žižek's and Deleuze's projects is apparent, preventing us from uniting them within a single dialectical movement. As Žižek himself explains: “The reality of the virtual [...] by this I mean efficacity, effectiveness, real effects produced, generated by something, which does not yet fully exist, which is not yet fully actual" $(2004 a)^{12}$. What is telling about this wording is that for all the radicality of introducing the theme of the virtual, it is the consequences and "the real effects" that it produces in actuality that remain the main focus of consideration. It is these effects that measure its degree of reality. As a result, for Žižek, the idea of retroactivity is not so much aimed at working with the virtual as it is intended to show the mechanism of its actualization. Of course, this actualization should be understood in a different way to the actualization of pre-established potential. But still, the fundamental moment of practical and theoretical freedom which, according to Žižek, dialectics provides, is related to the moment of the event of change in actuality, even if its essential characteristic is that this event is marked by a change in the virtual dimension. As for Deleuze, he instead conceives the highest moment of emancipation through the release of the virtual itself, the pure form of time and the pure difference. The idea of retroactivity, with which Žižek describes the virtual in its difference from the possible, is understood by Deleuze rather in the context of the latter:

[T] o the extent that the possible is open to 'realisation', it is understood as an image of the real, while the real is supposed to resemble the possible. That is why it is difficult to understand what existence adds to the concept when all it does is double like with like. Such is the defect of the possible: a defect which serves to condemn it as produced after the fact, as retroactively (Deleuze 1994: 212, own emphasis added) fabricated in the image of what resembles it. The actualisation of the virtual, on the contrary, always takes place by difference, divergence or differenciation. (Deleuze 1994: 212)

Only by understanding the virtual as pure difference, or "differenciation" of the Idea (or a problem), can we move to the problem of its actual-

12 Characteristically, Žižek gives this definition in his famous video lecture, The Reality of the Virtual, which practically reproduces the name of one of the subsections of the fourth chapter of Difference and Repetition: "The reality of the virtual: ens omni modo." 
ization: "differenciation" at the level of solutions. This can be said to be the essence of the dialectic posited by Deleuze.

The difference between the positions of Žižek and Deleuze in this relation can be described using Deleuze's own apparatus: as the difference of Chronos' point of view and that of Aion, as they are contrasted in Deleuze's Logic of Sense (Deleuze 1990: 162-169). Here we find two temporalities: Chronos, that sees all time as the present, and Aion, that always divides the present into the past and the future, with the present thus slipping away from him. Chronos is associated with the actual order of corporeal things and with depth, whereas Aion with the virtual order of simulacrum and surface. However, the fundamental and more subtle distinction is not drawn between them but instead between the proportion of actuality and virtuality within each of them. For Žižek, as already mentioned, the most important element is "unearthing, in the very heart of actuality, a secret striving towards potentiality” (2012: 291). In Deleuze's terms, this tendency can be described as "the becoming-mad of depth," or the moment when actuality suddenly starts to reveal a certain shift and inequality in relation to itself and to time, which is tied to actuality, and starts to "slip away from the present" (1990: 164). As for Žižek's metaphor, it points to a certain depth in which one can detect instability and agitation. However, in the case of Chronos such agitation does not leave the boundaries of actuality:

"' $[\mathrm{T}] \mathrm{o}$ sidestep the present' is precisely what becoming cannot do (for it is now becoming, and hence cannot leap over this "now"). [...] Chronos must still express the revenge taken by future and past on the present in terms of the present (own emphasis added), because these are the only terms it comprehends and the only terms that affect it”. (Deleuze 1998: 164)

Deleuze contrasts Chronos' “now" and Aion's “instant” (Deleuze 1990: 165-166). The "instant" also marks the becoming and deviation from the present, but in a different way from the "now" of Chronos. Here, what comes to the fore is not the transformation of actual things but the pure space of becoming of incorporeal effects. Deleuze compares them by considering two situations related to the temporal description of the event, which he conceives as a sort of deviation from the present.

The first hypothesis concerns depth, or Chronos, and the second the surface, or Aion: "if depth evades the present, it is with all the force of a 'now' which opposes its panic-stricken present to the wise present of measure" (Ibid.: 165). This thesis can be read in line with Žižek's interpretation of dialectics: in place of one order of actuality comes the new order of measure, as a result of "the becoming-mad of depth" event when the actual deviates from the present, revealing the virtual in itself-that 
which is inherent in the past and future. The foundational gesture of Žižek is related to the discovery of "the becoming-mad" within this new order.

" $[I] f$ the surface evades the present, it is with all the power of an 'instant,' which distinguishes its occurrence from any assignable present [italicized by the author] subject to division and redivision" (Ibid.: 165). It is this moment of coincidence between actuality and virtuality-not on the territory of the actual, but rather that of the virtual-that interests Deleuze the most. In this sense, the imperative of "asserting contingency," mentioned above, also has a completely different, ahistoric meaning in Deleuze's works: here, chance appears not just as one of the probabilities nor as the intervention of the pathological actual into the domain of pure virtual, ${ }^{13}$ but as an affirmation of "all chance" and a total game of chaos, in which there is no place for arbitrariness, and the actual and virtual transform into each other without mediation (Ibid.: 60, 243-248).

Of course, this virtual element is not completely detached from present time and actuality; however, their conjugation is perceived not as a measure of Chronos but as a paradoxical element-the present "without thickness," or "the present of pure operation, not of the incorporation," that should be thought of as "counter-actualization" (Ibid.: 169). Actuality understood from this perspective is not at all the same as how Žižek describes it, but is instead fundamentally multiple. Žižek does not accept this multiplicity-instead critiquing it-but seemingly misses the moment when this multiplicity derives from those very notions that he hastily attributes to the lexicon of the Hegelian dialectic.

Deleuze describes the unfolding of Aion in the same terms as the eternal return or the so-called third synthesis of time ${ }^{14}$ (Deleuze 1994: 85): "Aion is the eternal truth of time: pure empty form of time, which has freed itself of its present corporeal content and has thereby unwound its own circle, stretching itself out in a straight line" (Deleuze 1990: 165). According to Deleuze, it is this liberation of the pure and empty form of time in the third synthesis that makes up for the insufficiency of the memory of the second synthesis, dealing with the pure past, that which is so valued by Žižek. Virtuality is understood by Deleuze ambiguously: in the sense that it is present at different levels, in different syntheses and combinations. My thesis is that in interpreting the virtual, Žižek refers only to one of the levels of its unfolding, missing the one that is key for Deleuze, and therefore does not see a real lever in his philosophy that would help

13 This is approximately how this theme appears within Žižek’s works: “every idealizing/universalizing negativity has to be attached to a singular, contingent, 'pathological' content" (2012: 316).

14 The theory of three syntheses of time is presented in Deleuze's work Difference and Repetition (1994). 
restart the machine of Hegel's dialectics in a different direction. This is most clearly seen in the case of the third concept here under consideration: the concept of repetition. Bringing the virtual and chance together under the common concept of retroactivity-both historic and logicalŽižek approaches another problem that Deleuze's philosophy and dialectic have in common: that of repetition. The fact is that Hegel's dialectics, indeed, deals with repetitions of the same at new logical levels. In the context of history, this repetition is thought of as the establishing of truth through error (Žižek 1989: 61-65). In Žižek's interpretation of such repetition, the whole capacity of the retroactivity mechanism is activatedincluding the assertion of contingency and the logic of the virtual. Yet Deleuze, as Žižek states, problematizes a different, "non-dialectical” repetition: that is, a repetition that does not go through sublation, but which, nevertheless, bears something new. In this sense, the repetition of Kierkegaard, Freud and Deleuze presents a real problem for (Hegel's) dialectics. ${ }^{15}$ Repetition is a non-conceptual difference, and its conceptualization is inextricably linked and coincides for Deleuze with the reinterpretation of difference as pure difference, independent from identity.

The pure past and the Idea, as shown above, adhere to the logic of retroactivity, and its mechanism can be described in the following way: a change in the domain of the virtual, that is, in the domain of Ideas, takes place "through the changes in actual things which express Ideas, since the entire generative power lies in actual things” (Žižek 2012: 138). However, with pure difference and repetition, the opposite is true:

Deleuze's thesis according to which New and repetition are not opposed, for the New arises only from repetition, must be read against the background of the difference between the virtual and the actual: changes which concern only the actual aspect of things are only changes within the existing frame, not the emergence of something really New-the New only emerges when the virtual support of the actual changes, and this change occurs precisely in the guise of a repetition in which a thing remains the same in its actuality. (Ibid.: 303)

Thus, if the virtual structure in a retrospective gesture is established as "always already" existing-due to the change in the order of actualityfor the situation of repetition the opposite is true: the new appears at the

15 Žižek states this in his later work on Hegel: "In Hegel, repetition plays a crucial role, but within the economy of Aufhebung: through a mere repetition, an immediacy is elevated into universality, a contingency is transformed into necessity [...] There is no place, within Hegel's system, for thinking 'pure' repetition, a repetition not yet caught in the movement of Aufhebung” (Žižek 2012: 308). In an earlier book on Deleuze, the repetition of Kierkegaard and Deleuze is still presented exclusively in the context of the logic of retroactivity (Žižek 2004b: 8-13). 


\section{Ksenia Kapelchuk}

level of the virtual, whereas the actual order remains unchanged. It may seem that here the ratio of the actual and virtual is inverted, but in fact everything remains in its place: the changes in the domain of the virtual still depend on the order of the actual, but in one case we had to deal with its changes, and in the second case with its becoming "stuck":

The New emerges when, instead of a process just "naturally" evolving in its flow of generation and corruption, this flow becomes stuck, an element (a gesture) is fixed, persists, repeats itself and thus perturbs the "natural" flux of (de)composition. This persistence of the Old, its "stuckness," is the only possible site of the rise of the New: in short, the minimal definition of the New is as an Old which gets stuck and thereby refuses to pass away. (Ibid.: 303)

Again, this definition is surprisingly accurate in the way in which it resonates with the Deleuzian characteristics of Chronos, who, according to Deleuze, is "inseparable from circularity and its accidents-such as blockages or precipitations, explosions, disconnections, and indurations" (Deleuze 1990: 165). What Žižek does not seem to pay attention to is the fact that Deleuze's understanding of becoming, repetition, and the New is related with a going beyond of the second synthesis and the logic of Chronos. ${ }^{16}$

This is how Žižek links the problem of repetition to Hegel's dialectic: although Hegel understands repetition through sublation-leaving bare mechanical repetition unrecognized within his dialectic-it remains at the level of "action." Dialectic allows for the interiorization of the external, and therefore Žižek transplants pure repetition to the very heart of the sublation process.

16 According to Deleuze, to justify the latter, Aion is required (pure difference, the third synthesis of time, eternal return, the differentiating paradoxical element): redefining the proportion of actuality and virtuality, allowing us to go beyond identities and contradictions, negation and equivalence. Otherwise we remain at the level of representation. Such a definition of the virtual suggests a redefinition of actuality, so that it becomes impossible to apply Žižek's counter-argument: “is not 'pure' virtual difference the very name for actual self-identity? Is it not constitutive of actual identity? More precisely, in the terms of Deleuze's transcendental empiricism, pure difference is the virtual support or condition of actual identity: an entity is perceived as '(self-)identical' when (and only when) its virtual support is reduced to a pure difference" (Žižek 2012: 302). The entire project of Deleuze's dialectics is aimed at separating these two levels: the level of representation-where difference is subordinate to identity-and the level where the Idea as the problematic differentiating pure difference (or disguised repetition) crystallizes. The latter allows us to interpret actuality not as the territory of identity and equivalence, but as a space of differenciation. 
In Kierkegaardian-Freudian pure repetition [...] the dialectical movement of sublimation encounters itself, its own core, outside itself, in the guise of a "blind" compulsion to repeat. It is here that we should apply the great Hegelian motto concerning the internalizing of the external obstacle: in fighting its external opposite, blind non-sublatable repetition, the dialectical movement fights against its own abyssal ground, its own core; in other words, the ultimate gesture of reconciliation is to recognize in this threatening excess of negativity the core of the subject itself. (Žižek 2012: 314-315)

In this way, Žižek presents "the pure repetition"-i.e. the repetition of Kierkegaard, Freud, and Deleuze-not so much as an independent problem but as "an answer to the Hegelian problem": the rejection of Hegel's philosophy in this interpretation means the loss of the dimension in which it acquires its subversive meaning (Ibid.).

But here we must object, because the term "pure repetition" to which Žižek refers is not quite Deleuzian (and not quite Kierkegaardian either). The notion of repetition is indeed introduced by Deleuze as anti-Hegelian in the sense that it does not undergo mediation and sublation. He continues in this sense the line of Kierkegaard, one of the first philosophers to raise this topic in modern philosophy. However, Žižek describes this concept as non-cumulative and mechanical, following, as it seems, Freud in particular: the compulsion to repetition is the predominant theme of psychoanalysis. As for Deleuze, of course, he also pays a fair amount of attention to it, but in general his concept of repetition with its anti-Hegelian pathos develops a different argument.

Their divergence can be summarized as follows: Deleuze, speaking of non-mediated repetition-which is not subject to sublation-describes repetition as a notion belonging to the dimension of the virtual. It is this repetition that Deleuze deems to be non-mediated, but not "pure" at all, neither bare nor mechanical; instead it is "costumed" and "disguised," while Žižek in his analysis refers to the actual aspect of mechanical repetitions. Yet to Deleuze, these appear as "bare" repetitions too, not opposed to identity, negation or sublation. The task of Deleuze's dialectical project is to point to the intersection where one can choose a different path and place them within a different, unrepresentative perspective.

Deleuze, in his call for a conception of pure difference, is far from asserting "pure repetition." His thesis is that "[t]he powers of repetition include displacement and disguise" (Deleuze 1994: 288), whereas his task consists in conceiving "the bare repetition" as the effect of "disguised repetition": "[r]epetition is truly that which disguises itself in constituting itself, that which constitutes itself only by disguising itself. [...] There is no bare repetition that may be abstracted or inferred from the disguise itself. The same thing is both disguising and disguised" (Ibid.: 17). 
Both the actual and virtual processes bear the name of repetition at the same time. With this, the problematization of actual, mechanical repetition, according to Deleuze, does not exclude but even provokes a "Hegelian" reading through identity, negation, and so forth. Deleuze's discovery is related not so much to actual as to virtual repetition - that is, to the repetition that takes place at the level of the virtual. Here Deleuze has a whole system of the distribution of repetition, in which mechanical repetition is found to be only the first step (Ibid.: 294-297). However, if we analyze a number of Deleuze's techniques-such as, for example, the movement from the first synthesis of time (the present, "Habitus") to the second (the past, "Mnemosyne") as a justification for the first-it is hard not to recognize the familiar techniques of Hegelian dialectics. In addition, the third synthesis of time-justifying the first two and at the same time breaking with both representation and the very logic of justification-arrives at the level of the virtual and in a sense appears as a (rather dialectical) means of going beyond dialectics. ${ }^{17}$ Perhaps there is indeed a blind spot in Deleuze's philosophy that refuses to see in the Hegelian message anything but the reduction of pure difference to contradiction and ultimately to identity, whereas perhaps the contradiction itself should be read as an interpretation, as an attempt to approach the problem of pure difference.

In light of these three reflexive shifts, as analyzed above-beginning with Deleuze's critical position toward Hegel, moving on to Žižek's interpretation Deleuze through Hegel, and returning to Deleuze's stance and its distinction from Žižek's view-we can finally see a new perspective opening, in which it becomes possible to perform another displacement: to interpret Hegel's dialectic from the point of view of Deleuze's. And if Žižek's texts allow us to read Deleuze in the light of the Hegelian dialectic, then possibly the reverse operation-reading Hegel not from the explicit point of view of Deleuze, but from the point of view of his own dialectic-can again redefine the essence of the dialectical movement and rewrite its prehistory.

Translated from the Russian by Maria Afanasyeva

${ }^{17}$ In a sense, this very transition to the third synthesis, as well as the "inversion" of the actual, is most reminiscent of Hegel's technique from The Phenomenology of Spirit, where in order to distinguish the sensible and the supersensible worlds, Hegel insists on the threefold division of this operation: the sensible world does not simply reveal the other in the supersensible world, but the supersensible world has to undergo another inversion inside itself and become "the inverted world" in order to relate again with the sensible world (Hegel 2018: 95-97). 


\section{For Deleuze}

\section{References}

Badiou, Alain (2006). Deleuze: The Clamor of Being. Minneapolis: University of Minnesota Press.

Buck-Morss, Susan (2009). Hegel, Haiti, and Universal History. Pittsburgh: University of Pittsburgh Press.

Comay, Rebecca (2011). Mourning Sickness: Hegel and the French Revolution. Stanford: Stanford University Press.

Deleuze, Gilles, and Felix Guattari (1983a). Anti-Oedipus. Capitalism and Schizophrenia. [1972]. Trans. Robert Hurley, Mark Seem, and Helen R. Lane. Minneapolis: University of Minnesota Press.

Deleuze, Gilles (1983b). "Plato and the Simulacrum.” Trans. Rosalind Krauss. October 27: 45-56.

Deleuze, Gilles, and Félix Guattari (1987). A Thousand Plateaus. Capitalism and Schizophrenia. Trans. Brian Massumi. Minneapolis: University of Minnesota Press.

Deleuze, Gilles (1990). Logic of Sense [1969]. Trans. Mark Lester. London: Athlone.

Deleuze, Gilles (1994). Difference and Repetition [1968]. Trans. Paul Patton. London: Athlone.

Deleuze, Gilles, and Felix Guattari (1994). What is philosophy? [1991]. Trans. Hugh Tomlinson and Graham Burchell. New York: Columbia University Press.

Deleuze, Gilles (1997). Cinema 1. The Movement-Image [1983]. Trans. Hugh Tomlinson. Minneapolis: University of Minnesota Press.

Deleuze, Gilles (2006). Nietzsche and Philosophy [1962]. Trans. Hugh Tomlinson. London: Continuum.

Hegel, Georg Wilhelm Friedrich (2010). The Science Of Logic [1813 and 1816]. Trans. George Di Giovanni. Cambridge: Cambridge University Press.

Hegel, Georg Wilhelm Friedrich (2018). The Phenomenology of Spirit [1807]. Trans. Terry Pinkard. Cambridge: Cambridge University Press.

Kaufman, Eleanor (2012). Deleuze, the Dark Precursor: Dialectic, Structure, Being. Baltimore: The Johns Hopkins University Press.

Kralechkin, Dmitriy (2006). Deleuze bez oslozhneniy [Deleuze without complications]. Censura.ru.

Kralechkin, Dmitriy (2007). Antiposlesloviye perevodchika. Kritika ne v fokuse. [Translator's anti-afterword. Criticism out of focus]. In Anti-Oedipus: Kapitalizm i shizofreniya [Anti-Oedipus: Capitalism and Schizophrenia]. Ekaterinburg. [In Russian]

Malabou, Catherine (2004). La Plasticité au soir de l'écriture. Paris: Éditions Léo Scheer.

Malabou, Catherine (2009a). La Chambre du milieu, de Hegel aux neurosciences. Paris: Hermann.

Malabou, Catherine (2009b). Plasticity at the Dusk of Writing: Dialectic, Destruction, Deconstruction. New York: Columbia University Press.

Malabou, Catherine, and Judith Butler (2010). Sois mon corps: Une lecture contemporaine de la domination et de la servitude chez Hegel. Paris: Bayard.

Sinnerbrink, Robert (2006). “Nomadology or Ideology? Žižek’s Critique of Deleuze.” Parrhesia, 1: 62-87. 


\section{Ksenia Kapelchuk}

Smith, Daniel W. (2004). “The Inverse Side of the Structure: Žižek on Deleuze on Lacan.” Criticism, 46.4: 635-650.

Zandvoort, Bart, and Rebecca Comay, eds. (2018). Hegel and Resistance. London: Bloomsbury.

Žižek, Slavoj (1989). The Sublime Object of Ideology. London \& New York: Verso.

Žižek, Slavoj (1997). The Plague of Fantasies. London \& New York: Verso.

Žižek, Slavoj (2004a). The Reality of the Virtual. Youtube. https://www.youtube.com/ watch?v=gBRToxGyKZo

Žižek, Slavoj (2004b). Organs without Bodies: On Deleuze and Consequences. London and New York: Routledge.

Žižek, Slavoj (2007). “Filosofia nachinaetsya s Kanta y zakanchivaetsya Gegelem.” [Philosophy starts with Kant and ends with Hegel]. Logos 1.58: 3-13.

Žižek, Slavoj (2012). Less Than Nothing. Hegel and the Shadow of Dialectical Materialism. London and New York: Verso. 